\title{
OBRAZ PUBLIKA MĚSTSKÉHO DIVADLA V OLOMOUCI
}

Německé městské divadlo bylo po většinu doby své existence (1770-1920) hlavní kulturní institucí v Olomouci. Po zákazu českých představení na této scéně v 80. letech 19. století reprezentovalo až do vzniku Československa německou majoritu ve městě. Skladbu abonentního publika olomouckého městského divadla můžeme dnes rekonstruovat jen s obtížemi, a to pouze na základě nepř́mých indicií. Př́slušné prameny, jako například pokladní knihy, se nedochovaly, nebot' byly s dalšími cennými dokumenty divadelního archivu zničeny při povodni v Olomouci v ř́jnu roku 1930. V této studii se přesto pokusíme rekonstruovat rozvrstvení publika $\mathrm{v}$ prostoru hlediště městského divadla a na základě informací v dobové místní publicistice, úředních záznamech jednání městských zastupitelů či v dalších dokumentech uložených v Archivu města Olomouce charakterizovat specifika, vkus, národnostní rozložení či dynamiku jeho proměny.

\section{Rozvrstvení publika v prostoru divadelního hlediště. Městská elita}

Podobně jako $\mathrm{v}$ případě jiných evropských kamenných divadel této doby jádro návštěvníků olomouckého divadla představovali měšt’ané. ${ }^{1}$ Sociální stratifikaci divadelního publika lze dobře odečíst ze způsobu jeho rozsazení v prostoru hlediště divadla na olomouckém Horním náměstí postaveném v roce 1830 podle návrhu vídeňského architekta Josefa Kornhäusela. ${ }^{2}$ Podobně jako v jiných německých či rakousko-uherských divadlech publikum sedící v parteru a v lóžích sestávalo

1 Mezi typické vzorce chování měštanů druhé poloviny 19. století patřila snaha zařadit se do společenského života, s čímž souvisí i veřejná demonstrace pozitivního vztahu ke kultuře návštěvou divadla či koncertu. Viz HOREJSEK, J. Měšt’anstvo ve druhé polovině 19. století a jeho politická, společenská, sociální a kulturní aktivita (dlouhodobé tendence na př́kladu Olomouce a olomouckých měšt’anů). In Studie k sociálním dějinám 19. století, sv. 5. J. Macháčková - J. Matějček (eds.). Opava - Praha - Kutná Hora: Slezský ústav SZM, 1995, s. 45. 
z představitelů tehdejší buržoazie, vyššího úřednictva a městské inteligence, tedy zejména majitelů továren, ředitelů, bankéřů, právníků, lékařu či úředníků. Tuto skladbu dokumentuje i složení divadelního výboru olomouckého zastupitelstva, který na dění v městském divadle od konce 70 . let 19. století dozíral. Jeho členové v posledních čtyřech desetiletích existence německé olomoucké scény, tedy $\mathrm{v}$ období, jež nás bude $\mathrm{v}$ této studii zajímat, patřili také $\mathrm{k}$ pravidelným návštěvníkům divadla. ${ }^{3}$

Takto např́íklad v roce 1886 byl předsedou divadelního výboru Adolf Thannabaur, ředitel vyšší reálky. $\mathrm{K}$ velkopodnikatelům pak náleželi místopředseda divadelního výboru a pozdější olomoucký starosta, majitel textilní továrny Carl Brandhuber, majitel strojírenského podniku Raimund Nietsche a Eduard Hamburger, jenž vlastnil sladovnu a současně byl nájemcem dvou pivovarů. Maloburžoazii zastupovali mezi tehdejšími členy divadelního výboru obchodník s kořením Josef Englisch, obuvník Franz Hartwich či optik a majitel domu Heinrich Sachs. ${ }^{4} \mathrm{~V}$ divadelním výboru byli rovněž právníci a vysocí úředníci - zemský advokát a první tajemník obchodní komory Conrad Bayer a Carl Buchberger, zemský soudní rada, a rovněž zubní lékař a majitel domu Franz Patloch. ${ }^{5}$ Obdobné sociální složení divadelního výboru měl divadelní výbor i o čtvrtstoletí později, kdy v jeho čele stál knihkupec a majitel domu Friedrich Grosse, zastupoval ho ředitel měšt’anské školy Josef Föhner. Mezi členy divadelního výboru najdeme tehdy ještě další dva ředitele škol - ředitele gymnázia Adolfa Daumanna a ředitele měšt’anské školy Theodora Knauteho. Podnikatelskou elitu ve městě reprezentoval velkoprůmyslník a továrník Robert Primavesi, v menším měřítku rozvíjeli podnikatelské aktivity i další členové divadelního výboru - majitel sladovny Friedrich Fischel, továrník a majitel domu Eduard Mayer, obchodník s kůží Max Deutsch, mydláŕ Karl Weiß a kavárník Johann Rupprecht. Úřednictvo zastupoval pak ředitel poštovního úřadu Josef Benda, tajemník obchodní komory Dr. Hans Krick a zemský soudní rada Dr. Oswald Theimer. Mezi tehdejšími členy divadelního výboru byli ještě notář Richard Mader a zubní lékař Dr. Josef Schön. ${ }^{6}$

3 V pozdější historii německého městského divadla v Olomouci dochází k výraznému posílení role města jako majitele divadla, a to zvláště od chvíle, kdy je divadelní ředitel zbaven povinnosti platit nájemné za propůjčenou budovu a velkou část provozních výdajů bere na svá bedra obec. Jejím výkonným orgánem se stal divadelní výbor (Theatercomité), jehož členové byli pravidelně voleni, obstarávali komunikaci s ředitelem a připravovali klíčová opatření, o nichž pak v hlasování rozhodovalo kolegium městských zastupitelů. V centru zájmu vedení města stála především operní představení pořádaná v olomouckém divadle, nebot' ta, bez ohledu na preference publika orientovaného od vpádu operety především na zábavnější formy hudebního divadla, reprezentovala uměleckou úroveň městského divadla.

4 Držba obytných domů a pronájem bytů se staly později hlavním zdrojem příjmů olomouckých měšt’anů (HOREJSEK, op. cit., s. 18), proto uvedení vlastnictví domu mělo stejnou důležitost (ne-li vyšší) jako informace o živnosti nebo povolání.

Statistisches Jahrbuch der königlichen Hauptstadt Olmütz I. Einleitungsband als Festschrift zum vierzigjährigen Regierungs-Jubiläum Sr. Majestät des Kaisers. Bearbeitet von Wilibald Müller, Olmütz: herausgegeben vom Gemeinderathe, 1888, s. 117-122. 


\section{Studenti, vojáci a drobní živnostníci}

Nejlevnější místa na galeriích či ke stání v parteru ${ }^{7}$ byla v průběhu týdne nejspíš obsazena skupinami studentů a v posádkové Olomouci pochopitelně i nižšími vojenskými šaržemi. Pro spodní sociální vrstvy byla návštěva divadla takřka nedostupná ze dvou důvodů. Zaprvé byla vstupenka př́liš drahá. Místo k sezení v parteru stálo v roce 188870 krejcarů, což bylo neúměrně mnoho např́ílad ve srovnání s tehdejšími cenami potravin (bochník chleba stál asi 6 krejcarů a půl kila hovězího masa 12 krejcarů). Řemeslnický mistr, jenž si ročně v 80. letech 19. století vydělal $180-190$ zlatých, ${ }^{8}$ mohl čas od času něco našetřit na návštěvu divadla, ale pro nádeníka žijícího z výdělku pohybujícího se okolo sta zlatých to byl nedostižný luxus. Druhým důvodem, proč mezi divadelními návštěvníky nebyli dělníci či jinak závislí pracující, byl začátek představení. Divadelní představení v Olomouci po mnoho let začínala již v 19 hodin, což bylo těžko slučitelné s pracovní dobou manuálně pracujících, i když ta byla na konci století snížena ,jen“ na deset hodin. Lze si jen těžko představit, že by po celodenní tvrdé dřině měl tehdejší př́íslušník vrstvy pracujících ještě energii k návštěvě divadla, byt' za nejlevnější vstupné na stání ( 20 krejcarů), jež by si snad mohl dovolit. Dlouhý pracovní den však měli i mnozí př́slušníci maloburžoazie. Ředitel Leopold Schmid ${ }^{9}$ se na konci prvního desetiletí 20. století snažil posunout začátek představení aspoň na pưl osmou večerní, což zdůvodňoval tím, že tímto umožní obchodníkům majícím otevřeno až do večera či různým jiným živnostníkům chodit do divadla i ve všedních dnech. Hlavními dny pro návštěvu divadla byl tedy sobotní a nedělní večer. Protože v těchto dnech chodili do divadla i príslušníci nižších stavů, byly pro tyto dny vyhrazeny především formy zábavného divadla, a to zvláště opereta či veselohra. Opera, jež nebyla preferovaným divadelním žánrem nižších sociálních vrstev, se tak zpravidla hrála jen přes týden. Se sílícím sociálním státem se na konci 19. století začala pořádat $\mathrm{v}$ evropských divadlech tzv. lidová představení s redukovanou cenou vstupenky. Někteří skladatelé či umělci však považovali takové slevy za degradaci jejich umění, takto si např. v roce 1893 Wagnerovi dědicové vymohli zákaz uvádění Tristana a Isoldy a Tannhäusera na představeních se sníženým vstupným. ${ }^{10} \mathrm{~V}$ Olomouci lidová představení konaná v neděli a o svátcích o půl čtvrté odpoledne zavedl ředitel Stanislaus Lesser ${ }^{11}$ a pokra-

arbeitet von der Statistischen Kommission des Gemeinderates, Olmütz: im Verlage des Gemeinderates, 1911, s. 185-187.

7 Ke konci století usiloval ředitel Stanislaus Lesser o navýšení počtu dražších míst k sezení v parteru a prostor ke stání se zmenšoval.

8 LENDEROVÁ, M. - JIRÁNEK, T. - MACKOVÁ, M. Z dějin české každodennosti. Život v 19. století. Praha: Univerzita Karlova v Praze, Karolinum, 2011, s. 32-33.

9 Leopold Schmid vedl olomouckou scénu v letech 1904-1908 nejprve společně s Carlem Rübsamem, poté až do roku 1913 samostatně.

10 WALTER, M. „Die Oper ist ein Irrenhaus. “ Sozialgeschichte der Oper im 19. Jahrhundert. Stuttgart - Weimar: Verlag J. B. Metzler, 1997, s. 325.

11 Stanislaus Lesser (1840-1907) vedl olomoucké městské divadlo v letech 1896-1904. 
čovali v nich i jeho nástupníci v ředitelské funkci. Leopold Schmid vedle těchto lidových představení pořádal i tzv. školní představení pro mládež. Zatímco jejich obsah byl pod bedlivou kontrolou vedení města, jež dozíralo, aby byla mládeži nabízena hodnotná klasická dramata a operní díla německých velikánů, patřičně rozvíjející její národnostní smýšlení, lidová představení byla v rukou divadelního ředitele, jenž věděl, že cílovému publiku má smysl nabízet především operetu.

\section{Úřednictvo a střední stav}

Po rekonstrukci interiéru divadla v roce 1904 byl v městském olomouckém divadle maximální počet míst ke stání v př́zemí 210 , počet číslovaných sedadel na galerii činil 110 a maximální počet míst ke stání na galerii $225 .{ }^{12}$ Pokud se mělo vejít do divadla celkem tisíc návštěvníků, znamená to, že větší část byla vyhrazena právě pro levnější vstupné a tedy méně majetné publikum, přestože české publikum, jež se poprvé objevilo v prostorách německého divadla $\mathrm{v}$ listopadu 1918, mělo dojem, že dvě třetiny hlediště zabírají právě lóže určené pro „lepši společnost maloměsta“ (Pozor, 17. 11. 1918).

Přestože př́ijmově si nižší úřednictvo mohlo reálně dovolit levnější místa, nebot' se jejich plat v posledních desetiletích 19. století pohyboval jen kolem 600 zlatých ročně, ${ }^{13}$ př́slušnost $\mathrm{k}$ úřednickému stavu jim nařizovala vnější reprezentaci bez ohledu na skutečnou finanční situaci. Takže i tito návštěvníci v divadle seděli v parteru. Někteř́ ředitelé, vědomi si omezených finančních možnosti uurredníků, dávali jim slevy na vstupném. Když ředitel Emanuel Westen ${ }^{14}$ po svém nástupu do funkce tyto cenově redukované vstupenky pro úř́edníky zrušil, vyvolalo to jejich prudký nesouhlas a úředníci divadelnímu řediteli v tisku vyhrožovali, že do divadla přestanou chodit (Mährisches Tagblatt, 20. 9. 1887). Nejžádanějšími místy $\mathrm{v}$ olomouckém divadle byla podle různých dobových svědectví ta $\mathrm{v}$ parteru a ve druhém pořadí lóží, jež si střední stav mohl dovolit. Přesto měl např́klad ředitel Lesser v úmyslu v roce 1898 navýšit v divadle počet lóží, aby získal víc dražších míst, čímž chtěl vyřešit tehdejší problém návštěvnosti divadla. Městská rada Lesserovi nevyhověla, protože náklady na jejich zřizení byly př́liš vysoké. Později proto značně omezil počet míst $\mathrm{v}$ lóžích nabízených $\mathrm{v}$ předplatném, právě aby ponechal sedadla $\mathrm{v}$ lóžích k prodeji samostatných dražších denních vstupenek. Tato Lesserova obchodní strategie se však poněkud vymykala praxi jiných ředitelů, protože právě neabonované lóže na představeních často zely prázdnotou, což bylo v místním tisku provázeno rozhořčenými komentáři.

12 Viz ručně psaný dodatek v $\$ 11$ smlouvy uzavřené mezi obcí Olomouc a řediteli Rübsamem a Schmidem dne 10. 11. 1906.

13 VOŠAHLÍKOVÁ, P. Jak se žilo za časů Františka Josefa I. Praha: Nakladatelství Svoboda, 1996, s. 201.

14 Olomoucký rodák Emanuel Westen (1851-1906) vedl zdejší divadlo v sezoně 1887/1888. 


\section{Periodické problémy s návštěvností}

Olomoucké divadlo provázely periody lepší a horší návštěvnosti. Nejhorší situace $\mathrm{v}$ tomto ohledu byla $\mathrm{v} 80$. letech 19 . století, jež byla nejspíš zapříčiněna všeobecnou hospodářskou a agrární krizí, ekonomicky značně oslabující tehdejší obyvatelstvo. S odstupem let byla špatná návštěvnost 80 . let chápána také jako důsledek velkého požáru ve vídeňském Ringtheateru v prosinci roku 1881, po němž panovala i mezi olomouckým německým obyvatelstvem obrovská obava z každé návštěvy divadla. Pisatelé anonymního dopisu otištěného v Mährisches Tagblatt na počátku roku 1883 se s pohoršením podivovali nad tím, že ani členové zastupitelstva nechodí do divadla. „Pokud se nyní tak vlivní a vzdělaní mužové, kteři stojí na špici městské správy a u nichž lze předpokládat návštěvu divadla $z$ důvodu potřeby vzdělání, divadlu vyhýbaji, kdo bude toto mít za zlé úřednictvu, měštanstvu a kupeckému světu?" kladou si otázku tehdejší abonenti, sedící nejspíš na levnějších místech v parteru (Mährisches Tagblatt, 19. 1. 1883). Tyto krize návštěvnosti se však periodicky do olomouckého divadla navracely. Stav za Lesserova vedení na přelomu století byl někdy přirovnáván $\mathrm{k}$ tíživým osmdesátým létům, problémy nastaly i na konci prvního desetiletí 20 . století, kdy publikum vyměnilo prostory divadla za hlediště biografu. Obavy z toho, že nové prritažlivé médium zničí tradiční stánek umění, pronikly i do diskusí městské reprezentace. Někteří tehdejší olomoučtí zastupitelé požadovali okamžité odebrání koncese zdejšímu majiteli kina, což by tehdejší olomoucký starosta Karl Brandhuber ${ }^{15} \mathrm{~s}$ radostí přijal, kdyby k tomu měl oprávnění - koncesi udělovalo místodržitelství. Rovněž on byl však přesvědčen, že ,proti provozu kina je nutno energicky vystupovat, protože není ničím jiným než vysokou školu zločinu“, jak prohlásil na jednání kolegia městských zastupitelů. ${ }^{16}$ Ředitel Leopold Schmid ve snaze přilákat do divadla víc lidí posunul začátek představení a cenově rozlišil sedadla v parteru. Méně movití nižší úředníci chtějící sedět v př́izemí si tak mohli zvolit zadní levnější řady. Vnější společenské okolnosti vedly k odlivu publika i v letech bezprostř̌edně předcházejících I. světové válce, kdy městští zastupitelé konstatují př́ičiny nezájmu zdejšího publika o divadlo ve všeobecném zdražování a hospodářském poklesu a vůbec $\mathrm{v}$ nepříznivé atmosféře ve společnosti v době balkánských válek. ${ }^{17}$

Divadlo zelo prázdnotou zvláště při provedeních tradičních repertoárových oper, především opery z počátku 19. století olomoucké publikum od přelomu století už nezajímaly. Ředitelé si slibovali lepší návštěvnost zejména od benefičních představení oblíbených zpěváků. Málo navštívena bývala často i činohra, jen opereta se těšila vždy dobrému zájmu publika. Vedení města někdy vidělo příčiny malé

15 Karl Brandhuber (1846-1934) působil jako olomoucký starosta v letech 1896-1918.

16 Protokoll über die Sitzung des Stadtverordneten Collegiums der k. Hauptstadt Olmütz um 8. 7. 1912. SOkA Olomouc, M1 - 1, AMO, Knihy, sign. 2092.

17 Protokoll über die Sitzung des Stadtverordneten Collegiums der k. Hauptstadt Olmütz um 7. 10. 1912. SOkA Olomouc, M1 - 1, AMO, Knihy, sign. 2092. 
návštěvnosti divadla ve zdražování vstupného, o něž ředitelé opakovaně město žádali, to však jen nerado vycházelo vstř́c s ohledem na své voličstvo. Městská reprezentace prostřednictvím místního tisku opakovaně povzbuzovala Olomoučany $\mathrm{k}$ návštěvě městské scény. Takto před začátkem jediné olomoucké sezony ředitele Emila Schönerstädta ${ }^{18}$ vyzývá divadelní výbor městské rady místní občany, aby svou lepší návštěvností přrispěli novému řediteli k úspěšnému provozu divadla, jež se nacházelo v posledním roce direktoriátu jeho předchůdce Emanuela Raula ${ }^{19}$ v troskách (Mährisches Tagblatt, 28. 8. 1883). Výhradně Němci zastoupené vedení obce káralo německé obyvatelstvo za to, že svou netečností k divadlu zavdává podnět ke zlomyslnostem Čechů a apelovalo na německé národní cítění, „o němž se nemá jen mluvit, ale má být prokazováno podporou německého uměni" (Die neue Zeit, 12. 2. 1898). „Divadelní instituce musí v tomto městě vstoupit do srdce každého Němce, jenž by si měl vyhradit pro její návštěvu jeden až dva dny v týd$n u$, " hlásali městští zastupitelé. ${ }^{20}$ Nejnaléhavěji bylo k návštěvnosti podněcováno německé publikum po vzniku československého státu, tedy v době, kdy reálně hrozilo předání dosud německého divadla do českých rukou. Návštěva divadla se stala součástí boje o národní německé zájmy.

\section{Národnostní zastoupení publika}

V publiku městského divadla $v$ Olomouci převládali Němci. Podíl českého publika byl v olomouckém městském divadle ve sledované době velmi malý a v průběhu let se ještě snižoval jednak kvưli sílícímu vzájemnému národnostnímu odporu, $\mathrm{v}$ jehož důsledku panoval zákaz českých představení a později také děl českých autorů v olomouckém městském divadle, ${ }^{21}$ ale rovněž kvůli rozvoji českého divadelního provozu ve městě. ${ }^{22} \mathrm{Již} \mathrm{ředitel} \mathrm{Westen} \mathrm{si} \mathrm{stěžoval} \mathrm{v} \mathrm{době} \mathrm{po-}$ tíží s návštěvností divadla v 80 . letech 19 . století na to, že se české obyvatelstvo německému divadlu vzdálilo. Nejvíc veřejně kritizoval nucenou absenci českého publika ředitel Stanislaus Lesser, jemuž jeho postoj také přitížil v jednáních s obecní radou. Rovněž ředitelé Rübsam a Schmid by uvítali Čechy v divadle

18 Emil Schönerstädt (1830 -?) vedl olomoucké divadlo v sezoně 1883/1884.

19 Emanuel Raul (1843-1916) vedl olomoucké divadlo v letech 1880-1883.

20 Protokoll über die Sitzung des Stadtverordneten Collegiums der k. Hauptstadt Olmütz um 28. 8. 1905. SOkA Olomouc, M1 - 1, AMO, Knihy, sign. 2085.

21 K tomu městská rada přistoupila na popud Německého spolku po uvedení Smetanova Dalibora na podzim roku 1897.

22 Pokud Češi navštěvovali německou scénu, lze předpokládat, že nikoli kvůli činohře, zajímalo je nejspíš hudební divadlo. Kromě operních představení Trnkovy divadelní společnosti či několika pohostinských zájezdů profesionálního operního souboru brněnského Národního divadla v letech 1907, 1912 a 1913 se o systematický český operní provoz ve městě zvláště na konci prvního desetiletí 20. století snažil především pěvecko-hudební spolek Žerotín. Od roku 1910 proniká do repertoáru Žerotína stále více opereta, což možná bylo také důvodem dalšího podstatného odlivu části českého publika z německého městského divadla. 
z pragmatických důvodů - německé publikum mizelo v nových městských biografech a české by jeho absenci mohlo zacelit.

Zatímco Němci byli k návštěvě městského divadla vybízeni, se stejnou naléhavostí česká strana své soukmenovce nabádala $\mathrm{k}$ absenci v něm. Po jediném uvedení Smetanova Dalibora v olomouckém městském divadle v roce 1897 komentuje český deník Pozor početné české zastoupení v publiku s velkou nelibostí a vyzývá Čechy, aby do německého divadla např́ště nechodili: „České obecenstvo necht' jde tam výminkou!“" (Pozor, 16. 11. 1897).

Nová situace nastala po roce 1918. Vzhledem k tradiční sociální skladbě divadelního publika, jíž se olomoucké městské divadlo nijak neodlišovalo od evropských divadel té doby, panovala v prvních chvílích Československé republiky mezi Němci skepse, že v Olomouci nebude tolik majetných a vzdělaných Čechů, jež by divadelní hlediště zaplnili. Čechům byla v bojích o společné divadlo předhazována malá kulturní vyspělost, které si ovšem byla vědoma i česká strana a snažila se organizovaně přitáhnout do divadla i Čechy z přilehlých vesnic či měst. Ostatně s větším počtem divákủ z blízkých oblastí či měst počítal i německý provoz divadla a vedení města $\mathrm{k}$ tomu přistupovalo vstřícně, jak je zřejmé z jednání městské rady, jež se snažila zajistit přepravu přespolních návštěvníků z nádraží do divadla.

\section{Divadlo jako místo zábavy a demonstrací Olomoučanů}

Pro olomoucké publikum, podobně jako pro publikum jiných tehdejších divadel, nebyla návštěva divadla jen uměleckým zážitkem, ale také společenskou událostí. Lidé tehdy navštěvovali divadlo několikrát do týdne, což znamená, že přirozeně viděli mnohokrát stejné dílo. K malé obměně docházelo především v operním repertoáru. Divadelní ředitelé byli podle smlouvy, již uzavírali s obcí Olomouc při svém nástupu do funkce, povinováni uvést jen dvě operní novinky ročně, což však nezrŕ́dka nedodrželi. Opery tedy abonenti velmi dobře znali a jejich sledování nemuselo být proto při běžném repertoárovém provozu tak soustředěné. To platilo především pro publikum sedící v lóžích, jež umožňovaly jejím návštěvníkům separovat se a vést společenskou zábavu i v průběhu představení. Ve způsobu recepce se proto nájemci lóží značně odlišovali od publika v př́zemí. Jejich chování však vyvolávalo mezi ostatními divadelními návštěvníky mnohé projevy nesouhlasu, jak např́íklad čteme $\mathrm{v}$ jedné novinové kritice, jejiž autor nabádá návštěvnice lóží, aby např́iště „svým tlacháním nerušily ostatní publikum sedicí v parteru a svá místa přenechaly jiným, jež víc prahnou po uměni" (Die neue Zeit, 27. 10. 1895). Operní publikum se v Olomouci chovalo neukázněně zvláště v průběhu operní předehry. Mnohokrát bylo v tisku nabádáno k včasnému př́íchodu do divadla a upozorňováno, že i předehra je součástí operního díla (Mährisches Tagblatt, 1. 10. 1884).

Olomoucká operní představení byla někdy také narušována najatou klakou, již si za volnou vstupenku kupovalo vedení divadla nebo jednotliví zpěváci, často 
debutanti. Klaka, kterou určitě netvořili vážení a dobře postavení měšt’ané, ale spíš studenti či vojáci nižších šarží, mohla zachránit úplně špatné představení, dílo-propadák, nebo mohla třeba přispět k tomu, aby z malého úspěchu se stal velký úspěch. V dobovém místním tisku však čteme časté stížnosti na tyto „roztleskávače“, kteří prý vzbuzovali nevoli ostatních návštěvníků a noviny je proto nabádaly k uvědomění si nevhodnosti svého chování. Dobové novinové referáty podrobně zpravovaly o vnějších projevech publika, jimiž bylo dílo či jeho interpretace přijímáno či odmítáno. Noviny píší o frenetickém potlesku po každém brilantním výstupu, o předávání květinových darů a vavř́nových věnců. Publikum své interprety oslavovalo, ale i vysmívalo se jim. Takto bylo vystoupení zpěvačky Bertgenové v roli Elsy ve Wagnerově Lohengrinovi pokaždé, když vstoupila na jeviště, častováno syčením a hvízdáním, a to hlavně proto, že tuto roli tentokrát nezpívala publikem milovanější zpěvačka Wilfriedová (Mährisches Tagblatt, 4. 1. 1904). Olomoucké divadlo bylo mnohdy místem veřejných demonstrací politického rázu. Když na ředitele a kapelníka Carla Berghofa u dirigentského pultu při představení Prodané nevěsty bylo z publika pokřikováno „Berghof hinaus!“ (Die neue Zeit, 8. 4. 1895), nebylo to míněno kvůli jeho špatnému dirigentskému výkonu, ale jako projev nesouhlasu Německého spolku (Deutscher Verein) s uvedením díla českého skladatele. Ostatně Německý spolek vyhrožoval, že v divadle ,ztropi demonstrace ohromných rozměrü (Pozor, 23. 11. 1897) i v př́ípadě, že by se podruhé na scéně objevil Smetanův Dalibor.

\section{Publikum jako aktivní kritik}

Publikum olomouckého divadla bylo také obávaným kritikem dění v divadle i kolem něho. Místní německá publicistika s oblibou zveřejňovala dopisy svých čtenářů - divadelních abonentů. Převážně stížnosti adresovali divadelní návštěvníci rovněž obecní radě, jak o tom svědčí několik dochovaných většinou nepodepsaných dopisů či korespondenčních lístků. Divadelní návštěvníci ponejvíce komentovali aktuální repertoár $\mathrm{v}$ městském divadle. V roce 1900 si takto jistý anonymní abonent redakci Die Neue Zeit stěžoval, že namísto Beethovenova Fidelia byla do jeho abonentní řady vložena tehdy velmi populární opereta Geisha, která se však objevovala v předplatném již druhým rokem. „Divadelní abonenti by neměli být odbýváni ohryzanými kostmi a vymačkaným citrónem, abonenti maji právo být uspokojeni u dobře prostřeného stolu, nebot' jsou oporou divadla a jistí jeho existenci, “ píše rozzlobený majitel předplatného. Dále si stěžoval na opakující se repertoár, který tvoří především staré operety a obehrané veselohry, a vyslovil naději, že si jeho bezmocného výkřiku zastupujícího většinu abonentů povšimne zdejší divadelní výbor městské rady. ${ }^{23}$ Také o osmnáct let později míní zástupce olomouckého publika, že by tento orgán měl mnohem bedlivěji dohlížet na zvýšení umělecké úrovně, aby se tehdejší ředitel Schlismann-Brandt 
víc snažil ve všech oblastech, zvláště v opeře. ${ }^{24}$ Návštěvníci divadla opakovaně vytýkali olomouckým divadelním ředitelům prrílišnou délku přestávek mezi jednotlivými akty divadelních představení. V anonymním dopise, podepsaném jako „Mehrerere Theaterabonnenten“, míní jeho autoři, že „,v důsledku predlouhých pauz v uměleckém ohledu ztrácí dílo na jednotě. Pisatelé dopisu nabádají vedení obce, aby si uvědomilo, o kolik prostředků přichází kvůli tomu na poplatcích za osvětlení, které musí obec z poloviny hradit, když se každé takové představení natáhne nejméně o půl hodiny. „Zkrácením prestávek by také byla zkrácena divadelni služba všech zaměstnanců, kteři ostatně nijak vysoce za ni odměňováni nejsou," čteme dále v dopise. Anonymní pisatelé byli podle svých tvrzení nadto informováni, že by si dř́vější konec představení přáli i hospodští, kavárníci a další. Žádají proto obecní radu, aby tuto záležitost projednala a předala pokyn ke změně divadelnímu ředitelství. ${ }^{25}$ Autoři těchto dopisů opakovaně žádali městskou radu o to, aby zakročila proti nepř́stojnému pochybení divadelních ředitelů v organizaci divadelního provozu. Takto si v roce 1918 návštěvník veselohry Paula Franka Die blaue Perle [Modrá perla] stěžoval, že představení začalo se zpožděním v 7 hodin a 12 minut, poté byly vřazeny dvě meziaktní hudby a vše skončilo již o půl deváté. „Proč reditel Schlismann k tomu nepřidal ještě nějakou jednoaktovku?" táže se rozhorleně anonym a doporučuje: ,Měli byste ho už vic klepnout přes prsty!“26 $\mathrm{O}$ profesionální úrovni ansámblu v témže roce svědčí i další anonymní výtka divadelního návštěvníka, jenž popisuje tehdejší stav slovy: „snad všichni pánové $i$ dámy angažovaní v činohře museli současně $i$ v operetě zpivat a tancovat. “27 Publikum si vyhrazovalo právo kritizovat a ovlivňovat také záležitosti divadla, o nichž měla rozhodovat obec. Když v roce 1888 město neposkytlo divadelnímu řediteli Emanuelovi Westenovi subvence, o něž žádal, rozhodl se u publika poměrně oblíbený ředitel již po jednom roce olomouckého působení ukončit divadelní pacht. Deník Mährisches Tagblatt poté otiskl dopis čtenáře, dlouholetého divadelního abonenta, jenž se za toto rozhodnutí ostře pustil do městské rady. Tento anonymní pisatel byl přesvědčen, že se i v minulosti otcové města $\mathrm{k}$ ředitelům divadla právě spravedlivě nezachovali - dobrým ředitelům vstříc nevycházeli a těm, jejichž výkony byly špatné, pak neoprávněně v mnohých ohledech pomoc poskytovali subvencemi či povolením zvýšení cen vstupného. Čtenáŕ listu se proto jako návštěvník divadla s velkou pamětí všech událostí za poslední čtvrtstoletí u vedení města přimlouval za to, aby se pokusi-

24 Anonymní dopis adresovaný divadelnímu výboru, datován 23. 4. 1918. (SOkA, AMO, Registratura hospodářská 1874-1920, Divadelní ředitelé 1897-1918, Kart. 766, sign. L 2 i. č. 359.)

Anonymní dopis adresovaný městské radě datovaný 28. 2. 1906. (SOkA, AMO, Registratura hospodářská 1874 -1920, Divadelní ředitelé 1897-1918, Kart. 766, sign. L 2 - i. č. 359.) dářská 1874-1920, Divadelní ředitelé 1897-1918, Kart. 766, sign. L 2 -i. č. 359.) gistratura hospodářská 1874-1920, Divadelní ředitelé 1897-1918, Kart. 766, sign. L 2 i. č. 359.) 
lo Westena pro olomoucké divadlo udržet (MT, 17. 4. 1888). Naopak negativní reakci ze strany olomouckého publika vyvolalo, když bývalý olomoucký ředitel Ignaz Czernits, který divadlo vedl v letech 1868-1872, projevil zájem získat v Olomouci znovu ředitelské místo. Deník Die neue Zeit otiskl dopis anonymního divadelního abonenta, jenž dưrazně žádal místní obecní radu, aby nesvěřovala divadlo člověku, jenž byl ze svého dosavadního brněnského působiště odvolán pro to, že „sešlost stárím mu nedovolila divadlo nadále vést ${ }^{\text {‘28 }}$ (Die neue Zeit, 23. 2. 1880). Tomu nakonec městští zastupitelé vyhověli a v klání o místo nového ředitele městského divadla $v$ roce 1880 zvítězil Emanuel Raul, jenž vedl divadlo po dobu následujících tř́ let.

\section{Vkus místního publika}

Většina diváků v publiku však nejspíš nebyla schopna náročného kritického soudu a od návštěvy divadla žádala především zábavu a dobrou podívanou. Úvahy o špatném vkusu olomouckého publika vedli novinoví kritikové poměrně často. Především je rozčilovala jeho naprostá preference operety před operou či ostatními divadelními druhy. Divadelním ředitelům pak bylo doporučováno, aby se publiku $\mathrm{v}$ tomto ohledu nepodřizovalo a naopak ho vychovávalo kvalitními operními díly či klasickými dramaty. Kritikové nemohli pochopit jak to, že navzdory špatným výkonům operního souboru měl třeba Carl Stick, ${ }^{29}$ snad nejhorší ředitel ve vedení olomouckého městského divadla za dobu jeho existence, tak plné hlediště a osočovalo zdejší návštěvníky z nedostatku schopnosti rozeznat dobré od špatného. I přes skandální výkony místní publikum mnohdy nadšeně aplaudovalo, což kritiku vedlo k myšlenkám o totální nenáročnosti zdejšího auditoria. Stejnou měrou však tyto snahy o výchovu lepšího publika vadily samotným běžným divadelním návštěvníkům, jak ukazuje i dopis anonymního pisatele z roku 1913. Ten kritice vytýká, že ,přehliži větší část zdejšiho publika, která dvanáct hodin denně do úmoru dře a nechápe, že pak prostě nemá pochopení pro perverzni hypermoderni dila" (Mährisches Tagblatt, 22. 9. 1913). Myšlenka o poslání divadla jako chrámu vzdělání německého olomouckého obyvatelstva, již po léta hlásali představitelé města, tak v této konfrontaci s divadlem jako místem lidové zábavy nemohla vyjít jako vítěz.

Převážně německé publikum olomouckého divadla se nijak neodlišovalo od publika jiných provinčních scén, $v$ němž vzdělaní a kultivovaní návštěvníci rozhodně netvořili většinu. Zájmové preference můžeme ostatně dobře odhlédnout ze skladby repertoáru, jemuž vévodily zábavné žánry hudebního i činoherního divadla. Přece jen však jisté vkusové specifikum nalezneme - národnostně

28 Brněnské městské divadlo vedl Ignaz Czernitz v letech 1876-1879 (viz BONDI, G. Geschichte des Brünner deutschen Theaters 1600-1925. Brünn: Deutscher Theaterverein, 1924, s. 19-20). V době olomouckého konkurzu bylo Czernitsovi již 66 let. 
zjitřené vztahy ve městě byly kompenzovány demonstrací nacionálních symbolů v kulturním životě města a také v dominanci děl německých autorů na scéně městského divadla. Na piedestalu obliby olomoucké kritiky a dle jejích tvrzení i zdejšího publika stála pak operní díla Richarda Wagnera. Uvedení každého nového Wagnerova díla bylo v Olomouci provázeno až posvátným zájmem, přestože $\mathrm{k}$ důstojnému provedení kvůli omezeným inscenačním možnostem většinou nedocházelo. Snahy olomouckých divadelních ředitelů o internacionalizaci repertoáru byly omezovány ze strany vedení města, jehož orgán (kolegium městských zastupitelů) měl kompetenci zasáhnout do programové skladby scény. Dbát na německý charakter scény bylo ostatně smluvní povinností jejích ředitelů.

$\mathrm{K}$ výraznému přeskupení sociální skladby olomouckého divadelního publika dochází na sklonku I. světové války, a tedy v posledních letech existence samostatné německé scény v Olomouci, kdy do divadla začala chodit nová ekonomicky silná vrstva obyvatel, zbohatlá na válečném průmyslu. Nastalá situace je reflektována $\mathrm{v}$ hojných poznámkách $\mathrm{v}$ dobovém německém tisku a $\mathrm{s}$ jistou dávkou hořkosti i pozdějším autorem německých dějin Olomouce Johannem Kuxem: „To už nebylo to staré olomoucké měštanstvo prátelské $k$ divadlu se smyslem pro uměni; na drahých mistech v lóžich a prrizemi se ted' ostentativně roztahovala nově nastoupivši tř́da válečných spekulantü, šmelinárư a šejdiřri; stejná vrstva ,nových bohatých', kteři nyní plní každý večer lepši restaurace a lóže v kinech a triumfálně se povyšuji nad ožebračeným měštanským stavem. “" ${ }^{30} \mathrm{~V}$ těchto slovech čteme sentiment člověka heroizujícího zašlé minulé časy, jehož vzpomínky však nekorespondují s tím, co můžeme vyčíst v dobových pramenech.

Lenka Křupková (lenka.krupkova@upol.cz) je vedoucí Katedry muzikologie Filozofické fakulty Univerzity Palackého v Olomouci. Hlavními oblastmi jejího odborného zájmu jsou česká hudba 19. a 20. století, zvláště tvorba Vítězslava Nováka a Leoše Janáčka, hudební sociologie, dějiny německé operní scény v Olomouci a ediční činnost. V českých i zahraničních periodikách publikovala téměř pět desítek odborných studií a je autorkou tř́ knižních monografí.

\section{ABSTRACT \\ THE IMAGE OF THE AUDIENCE OF THE MUNICIPAL THEATRE IN OLOMOUC}

The study represents a probe into the structure of the audience of the German municipal theatre in Olomouc. It focuses foremost on the period from the seventies of the $19^{\text {th }}$ century until 1920 when the scene was handed over to the Czech administration. With regard to the absence of the theatre archives no documents that would help to determine the structure of its subscribers are available, thus only indirect resources and information are the source of knowledge of the contemporary theatre audience. Nevertheless, the author is trying to reconstruct the stratification of the audience in the auditorium of the municipal theatre with the help of information in the contemporary local

30 KUX, J. Geschichte der königlichen Hauptstadt Olmütz bis zum Umsturz 1918. Reichenberg und Olmütz: Verlag der Anstalt für Sudetendeutsche Heimatforschung - Verlag Franz Kraus Reichenberg, 1937, s. 468. 
journalism, official records of the meetings of the municipal representatives and other documents stored in the Archives of the City of Olomouc, and to characterize its specifics, taste, national collocation and the dynamics of its transformation in the determined period of time.

\section{Key words}

municipal theatre, Olomouc, 1875-1920, audience

\section{Bibliography}

Anonym. Eine „Geisha“ Vorstellung im Abonnement. Die neue Zeit, 28. 11. 1900.

BONDI, G. Geschichte des Brünner deutschen Theaters 1600-1925. Brünn: Deutscher Theaterverein, 1924.

HOREJSEK, J. Měšt’anstvo ve druhé polovině 19. století a jeho politická, společenská, sociální a kulturní aktivita (dlouhodobé tendence na př́kladu Olomouce a olomouckých měšt’anů). In Studie k sociálním dějinám 19. století, sv. 5. J. Macháčková - J. Matějček (eds.). Opava - Praha - Kutná Hora: Slezský ústav SZM, 1995.

KOPECKÝ, J. Německá operní scéna v Olomouci 1770-1878, I. Olomouc: Univerzita Palackého, 2012.

KUX, J. Geschichte der königlichen Hauptstadt Olmütz bis zum Umsturz 1918. Reichenberg und Olmütz: Verlag der Anstalt für Sudetendeutsche Heimatforschung - Verlag Franz Kraus Reichenberg, 1937.

LENDEROVÁ, M. - JIRÁNEK, T. - MACKOVÁ, M. Z dějin české každodennosti. Život v 19. století. Praha: Univerzita Karlova v Praze, Karolinum, 2011.

Statistisches Jahrbuch der königlichen Hauptstadt Olmütz I. Einleitungsband als Festschrift zum vierzigjährigen Regierungs-Jubiläum Sr. Majestät des Kaisers. Bearbeitet von Wilibald Müller. Olmütz: herausgegeben vom Gemeinderathe, 1888.

Der Statistischen Jahrbücher der königlichen Hauptstadt Olmütz V. Band 1905-1910. Bearbeitet von der Statistischen Kommission des Gemeinderates, Olmütz: im Verlage des Gemeinderates, 1911.

VOŠAHLÍKOVÁ, P. Jak se žilo za časů Františka Josefa I. Praha: Nakladatelství Svoboda, 1996.

WALTER, M. „, Die Oper ist ein Irrenhaus. “ Sozialgeschichte der Oper im 19. Jahrhundert. Stuttgart - Weimar: Verlag J. B. Metzler, 1997. 